\title{
Hillcrest v. Velikovsky
}

\section{An act of God?}

\section{Peter Watts}

The facts of the case were straightforward. Lacey Hillcrest of Pensacola, 50 years old and a devout Pentecostal, had been diagnosed with inoperable lymphatic cancer and given six months to live. Five years later she was still alive, albeit frail. She attributed her survival to a decorative silver-plated cross received from her sister, Gracey Balfour. Witnesses attested that Mrs Hillcrest's condition improved dramatically upon acquisition of the totem, a product of the Graceland Mint alleged to contain an embedded fragment of the original Crucifix of Golgotha.

On the morning of 27 June, Mrs Hillcrest and her sister patronized the Museum of Quackery and Pseudoscience, owned and managed by one Linus C. Velikovsky. The museum contained a variety of displays concerning discredited beliefs, theories and outright hoaxes perpetrated throughout American history. Mrs Balfour entered into a heated discussion with another museum patron at the Intelligent Design exhibit, temporarily losing track of her sister; they eventually reconnected at a display concerning psychosomatic phenomena, specifically placebo effects and faith healing. Mrs Hillcrest had evidently spent some time perusing the display and was subsequently described as 'subdued and uncommunicative.' Within a month she was dead.

The charge against Mr Velikovsky was negligent homicide.

The Prosecution called Dr Andrew deTritus, a clinical psychologist with an impressive record of expert testimony on any (and sometimes conflicting) sides of a given issue. Dr deTritus testified to the uncontested reality of the placebo effect, pointing out that 'attitude' and 'outlook' - like any other epiphenomenon of the brain - were ultimately neurochemical in nature. Belief literally rewired the brain, and the existence of placebo effects showed that such changes could have a real impact on human health.

Velikovsky took the stand in his own defence, which was straightforward: all claims presented by his displays were factually accurate and supported by scientific evidence. The prosecution objected to this point on the grounds of relevance but was, after some discussion, overruled.

Far from disputing Velikovsky's claims during cross-examination, however, the Prosecution used them to bolster its own

case. The defendant had deliberately set up shop in "one of our great country's most devout regions, with no thought to the welfare of the Lacey Hillcrests of the world". By his own admission, Mr Velikovsky had chosen Florida "because of all the creation museums", and had clearly been intent on rubbing people's noses in the alleged falsity of their beliefs. Furthermore, Mr Velikovsky was obviously well-versed in placebo effects, having built an erudite display on the subject. What did he think would happen, the Prosecution thundered, when he forced his so-called truth down the throat of

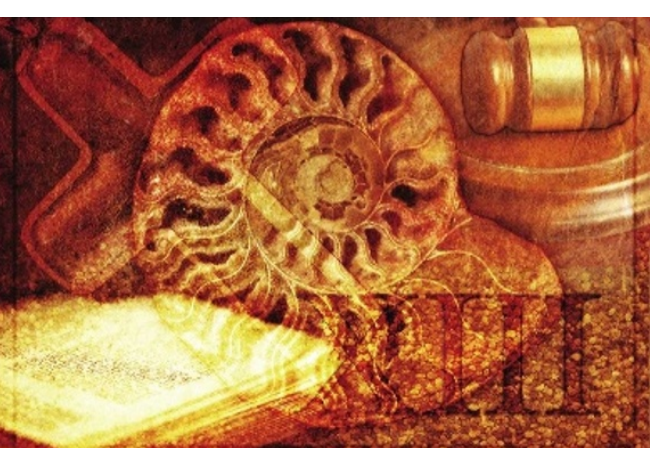

for herpes at $\$ 200 /$ treatment. Although this 'cure' had (unsurprisingly) proven ineffective, HerpBGone's council had cited Waber et al. 2008 (ref. 1) - which clearly showed that a placebo's efficacy increased with price - arguing that the treatment could have worked if Dexter had only paid more for it. As he had refused to do so (the same product was sold under a different name at $\$ 4,000)$, responsibility devolved to the plaintiff. The case had been dismissed.

It would have been a risky gambit. The parallels were far from exact. Instead, the Defence recalled Grace Balfour to the stand and asked whether she believed the Bible to be the revealed Word of God. Mrs Balfour readily conceded as much. It was her faith, she maintained, that allowed her to stay strong when that horrible man at the Creation display had mocked her with his talk of monkeymen and radioisotopes. She had seen fossils for what they truly were, the tests of faith described in Deuteronomy 13.

Asked then why her sister evidently did not share her strength of belief,

someone whose motto - knitted into her favourite throw-cushion - was If ye have faith the size of a mustard seed, ye shall move mountains? In telling 'the truth' Velikovsky had knowingly and recklessly endangered the very life of another human being.

Velikovsky pointed out that he hadn't even known Lacey Hillcrest existed, adding that needlepointing something onto a pillowcase did not necessarily make it true. The Prosecution responded that the man who plants landmines in a playground doesn't know the names of his victims either, and asked if the defendant's needlepoint remark meant that he was now calling Jesus a liar. The Defence objected repeatedly throughout.

The Defence had, in fact, fought an uphill battle ever since her client's swearing-in, during which Velikovsky had asked whether swearing to tell the truth on "a book of falsehoods" might undermine the court's alleged devotion to empiricism. The jury had seemed unimpressed by that question, and did not seem to have subsequently become more sympathetic.

Perhaps, if worst came to worst, their verdict might be set aside on technical grounds. But the closest thing to a precedent the Defence could unearth was Dexter v. HerpBGone, involving a mail-order scheme in which a mixture of sugar and baking soda had been marketed as a cure
Mrs Balfour allowed-somewhat reluc tantly - that "that horrid little Russian" had shattered her sister's faith with his "lies and deceit".

But did not the Bible itself arm the faithful against such wickedness? Did not Matthew warn that "false prophets shall rise, and deceive many"? Could Second Peter have been any more explicit than "There shall be false teachers among you, who shall bring in damnable heresies"?

Well, yes, Mrs Balfour allowed. Certainly, Velikovsky was a False Prophet. Sadly, as the Defence reminded her, false prophecy was not a criminal offence.

Ultimately there was no need to resort to technical exemptions. The jury, having been presented with the facts of the case, was unanimous: Lacey Hillcrest had not shown the courage for their conviction. Whose fault was it, after all, that her faith had been so much smaller than a mustard seed?

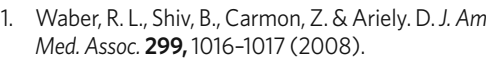

1. Waber, R. L., Shiv, B., Carmon, Z. \& Ariely. D. J. Am Med. Assoc. 299, 1016-1017 (2008).

Peter Watts's first story for Futures failed to provoke the desired howls of envious outrage from former colleagues who'd sneered at his decision to leave academia and write science fiction, and who then spent years trying desperately to get published in Nature. He hopes that more satisfying outbursts will result from repeated publication. 